\title{
Pre-sidedress Soil Nitrate Test Is Effective for Fall Cabbage
}

\author{
Joseph R. Heckman ${ }^{1}$ \\ Plant Science Department, Rutgers University, 59 Dudley Road, New \\ Brunswick, NJ 08901-8520
}

Thomas Morris ${ }^{2}$
Department of Plant Science, P.O. Box U-4067, University of Connecticut,
Storrs, CT 06269

J. Thomas Sims ${ }^{3}$

Department of Plant and Soil Science, University of Delaware, Newark, DE 19717

Joseph B. Sieczka
Long Island Horticultural Research Laboratory, Cornell University, 3059
Sound Avenue, Riverhead, NY 11901

Uta Krogmann 5

Environmental Sciences Department, Rutgers University, 14 College Farm

Road, New Brunswick, NJ 08901-8551

\author{
Peter Nitzsche ${ }^{6}$ \\ Rutgers Cooperative Extension of Morris County, P.O. Box 900 Court \\ House, Morristown, NJ 07963-0900
}

Richard Ashley $^{7}$

Department of Plant Science, P.O. Box U-4067, University of Connecticut, Storrs, CT 06269

Additional index words. Brassica oleracea, PSNT, nitrogen, nitrogen mineralization

\begin{abstract}
The pre-sidedress soil nitrate test (PSNT) was evaluated in 27 fields in New Jersey, 6 in Connecticut, 5 in Delaware, and 2 on Long Island in New York for its ability to predict whether sidedress $\mathrm{N}$ is needed to grow fall cabbage (Brassica oleracea var. capitata) as a double crop. Soil $\mathrm{NO}_{3}-\mathrm{N}$ concentrations measured on 20 field sites on the day of transplanting and 14 days after transplanting indicated that $\mathrm{NO}_{3}-\mathrm{N}$ concentrations over this time period increased, and that residues from the previous crop were not causing immobilization of soil mineral $\mathrm{N}$. The relationship between soil $\mathrm{NO}_{3}-\mathrm{N}$ concentration measured 14 days after transplanting and relative yield of marketable cabbage heads was examined using Cate-Nelson analysis to define the PSNT critical level. Soil $\mathrm{NO}_{3}-\mathrm{N}$ concentrations $\geq \mathbf{2 4} \mathrm{mg} \cdot \mathrm{kg}^{-1}$ were associated with relative yields $>\mathbf{9 2} \%$. The success rate for the PSNT critical concentration was $84 \%$ for predicting whether sidedress $\mathrm{N}$ was needed. Soil $\mathrm{NO}_{3}-\mathrm{N}$ concentrations below the PSNT critical level are useful for inversely adjusting sidedress $\mathbf{N}$ fertilizer recommendations. The PSNT can reliably determine whether fall cabbage needs sidedress $\mathbf{N}$ fertilizer and the practice of soil $\mathrm{NO}_{3}-\mathrm{N}$ testing may be extendable to other cole crops with similar $\mathrm{N}$ requirements.
\end{abstract}

Received for publication 12 Sept. 2000. Accepted for publication 9 May 2001. The research reported in this publication was supported by the New Jersey Agricultural Experiment Station and the Northeast Region Sustainable Agriculture Research and Education Program. Use of trade names does not imply endorsement of the products named nor criticism of similar ones not named.

${ }^{1}$ Extension Specialist in Soil Fertility. To whom reprint requests should be addressed. E-mail address: heckman@aesop.rutgers.edu.

${ }^{2}$ Extension Specialist in Soil Fertility.

${ }^{3}$ Professor of Soil and Environmental Chemistry.

${ }^{4}$ Associate Professor.

${ }^{5}$ Extension Specialist in Solid Waste Management.

${ }^{6}$ County Agricultural Agent.

${ }^{7}$ Extension Specialist in Vegetables.
Prediction of the nitrogen $(\mathrm{N})$ fertilizer needs of selected crops grown in humid regions can be improved by use of the presidedress soil nitrate test (PSNT) (Magdoff, 1991). This soil test is an in-season test used to predict soil $\mathrm{N}$ availability and the need for sidedress (supplemental) N fertilizer(Magdoff, 1991). When the PSNT measures $\mathrm{NO}_{3}-\mathrm{N}$ above a critical level in the soil (generally in the range of 20 to $30 \mathrm{mg} \mathrm{NO}_{3}-\mathrm{N} / \mathrm{kg}$ ) the application of sidedress $\mathrm{N}$ is not recommended (Binford et al., 1992; Blackmer et al., 1989; Fox et al., 1989; Heckman et al., 1996; Magdoff et al., 1984; Messinger et al., 1992). The identification of fields with adequate $\mathrm{N}$ available in the soil enables growers to avoid un- necessary applications of $\mathrm{N}$ fertilizer that has both economic and environmental benefits (Durieux et al., 1995; Guillard et al., 1999). The PSNT gained widespread acceptance during the 1990s as a tool to guide $\mathrm{N}$ fertilization in much of the corn (Zea mays L.) growing regions of the United States.

Although the PSNT was originally developed for use on field corn (Magdoff et al., 1984), there has been increasing interest in extending its use to other crops. The successful use of the PSNT for predicting sidedress N needs of sweet corn was reported by Heckman et al. (1995). The use of the PSNT as a N management tool has been reported for lettuce (Lactuca sativa L.) and celery [Apium dulce (Mill.) Pers.] (Hartz, 2000), and its use will likely be extended to additional vegetable crops.

The PSNT is especially useful when crops are grown on land to which manure has been applied or where forage crops are in the rotation (Heckman et al., 1995). The PSNT is useful for accessing $\mathrm{N}$ availability of previously applied $\mathrm{N}$ fertilizer in addition to $\mathrm{NO}_{3}-\mathrm{N}$ made available from mineralization of soil organic matter (Blackmer et al., 1989). In these situations, the PSNT often provides the information needed by growers to decide with confidence whether or not sidedress $\mathrm{N}$ fertilizer is needed. Considering the time, labor, and expense of soil sampling and analysis, there is little incentive for growers to measure PSNT values in soils that may be predicted to have low $\mathrm{NO}_{3}-\mathrm{N}$ concentrations. In general, the PSNT is most useful in cropping situations where significant amounts of mineral $\mathrm{N}$ may be expected in the soil before the period of major $\mathrm{N}$ uptake by the crop. Fall cabbage (Brassica oleracea var. capitata) is a crop that fits this profile. Cabbage and other cole crops are often grown as a double crop following the harvest of spring planted vegetable crops such as sweet corn, spinach (Spinacia oleracea L.), lettuce, peas (Pisum sativm L.), or beans (Phaseolus vulgaris L.). Mineral N remaining in the soil after the harvest of the spring crop, along with $\mathrm{N}$ that may become available from decomposing crop residues, may sometimes supply a sufficient amount of $\mathrm{N}$ to grow fall cabbage without applying sidedress $\mathrm{N}$ fertilizer. The objective of our research was to determine if the PSNT can predict whether sidedress $\mathrm{N}$ is needed to grow fall cabbage as a double crop.

\section{Materials and Methods}

Field calibration experiments were conducted at 40 locations ( 27 in New Jersey, 6 in Connecticut, 5 in Delaware, and 2 on Long Island in New York) over a 5-year period (1995-99). Sites were chosen to represent a wide range of soils in the Piedmont and the Atlantic coastal plain. All soils were well drained and had surface textures ranging from sandy loams to silt loams. Although not measured in this experiment, soil organic matter contents typically range from 5 to $20 \mathrm{~g} \cdot \mathrm{kg}^{-1}$ in sandy loams and from 25 to $35 \mathrm{~g} \cdot \mathrm{kg}^{-1}$ in silt loams. Sweet corn was grown as the spring 
crop preceding fall cabbage at all but two sites in which case soybean [Glycine max (L.) Merrill] was grown as a $\mathrm{N}_{2}$-fixing crop. Sweet corn was planted within $15 \mathrm{~d}$ of 1 May to ensure that sweet corn harvest would be completed before August. The weed control program for sweet corn used herbicides that would allow the fields to be cropped to fall cabbage. Sweet corn plant populations ranged from 50,000 to 63,000 plants/ha. The total amount of $\mathrm{N}$ fertilizer applied (banded and sidedressed) to the sweet corn averaged $180 \mathrm{~kg} \mathrm{~N} / \mathrm{ha}$, but ranged from 113 to $270 \mathrm{~kg} \mathrm{~N} / \mathrm{ha}$. After the fields were completely harvested of marketable ears, the sweet corn stalks were chopped and disked to prepare the soil for cabbage. At two sites, soybean was grown as a $\mathrm{N}_{2}$-fixing cover crop. Similarly, soybean plants were also chopped and disked before planting fall cabbage.

Cabbage seedlings were greenhouse grown for $\approx 5$ weeks. While in the greenhouse, plants received a weekly application of a water-soluble fertilizer, prepared by mixing $3 \mathrm{~g}$ of $15-30-15$ fertilizer/L of water and applying $\approx 27 \mathrm{~mL}$ of solution per plant. Cabbage seedlings were transplanted between 25 July and 15 Aug. during the experiment. At time of transplanting, 0-3 kg N/ha was applied to the field soil. Fertilizer P, K, S, and B were broadcast at the commercially recommended rate and incorporated with tillage. At each experimental site, cabbage transplants were spaced $35.6-\mathrm{cm}$ apart within the row and $76 \mathrm{~cm}$ between rows to establish populations of 36,889 plants/ha. Irrigation was applied after transplanting at all experimental sites except in Connecticut, where there was adequate moisture. Weed and insect control was performed by farmers or research station technicians according to commercial recommendations.

About 2 weeks after the cabbage was transplanted in the fields, PSNT soil samples were taken by collecting eight cores $(2 \mathrm{~cm}$ diameter $\times 30 \mathrm{~cm}$ deep) between the rows of each plot without sidedress N. PSNT soil samples were also taken using this same procedure on the day of transplanting at 20 experimental sites in New Jersey. After collection, the soil cores were composited by plot and immediately spread in a thin layer ( $1 \mathrm{~cm}$ thick) to dry on a greenhouse bench for $24 \mathrm{~h}$, or dried in an oven at $70{ }^{\circ} \mathrm{C}$ for $12 \mathrm{~h}$ (Griffin et al., 1995). The dry soil was crushed to pass a $2-\mathrm{mm}$ screen and was thoroughly mixed. Five grams of soil were added to $50 \mathrm{~mL}$ of $2 \mathrm{M} \mathrm{KCl}$ by shaking (reciprocating) for $30 \mathrm{~min}$ to extract $\mathrm{NO}_{3}$. Nitrate concentrations in the extracts were determined colorimetrically according to the method of Griffin et al. (1995).

Sidedress $\mathrm{N}\left(\mathrm{NH}_{4} \mathrm{NO}_{3}\right)$ rate treatments were applied 2 to 3 weeks after transplanting. The design was a randomized complete block with four replications at each site. A single research plot consisted of 10 rows with 10 plants per row. At 10 experimental sites conducted from 1995 to 1996 the $\mathrm{N}$ rates were $0,45,90,135$, and $180 \mathrm{~kg} \mathrm{~N} / \mathrm{ha}$. At 10 experimental sites conducted from 1997 to 1998 , the $\mathrm{N}$ rates were $0,45,90,135,180$, and $225 \mathrm{~kg} \mathrm{~N} / \mathrm{ha}$. At ten
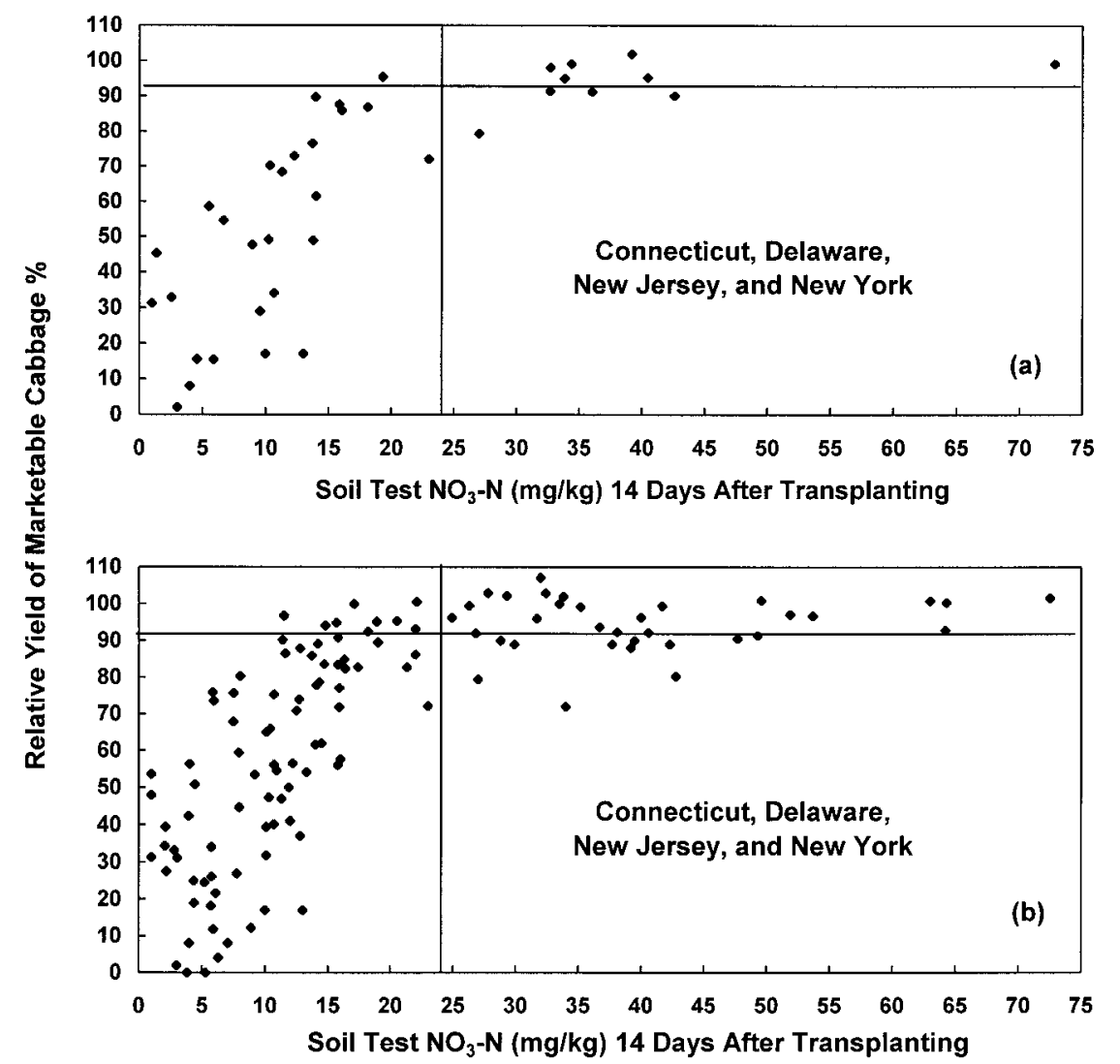

Fig. 1. Relative cabbage yield as a function of soil $\mathrm{NO}_{3}-\mathrm{N}$ concentration in surface $30 \mathrm{~cm}$ of soil; (a) data averaged across replications within an experiment site, (b) individual data points plotted.

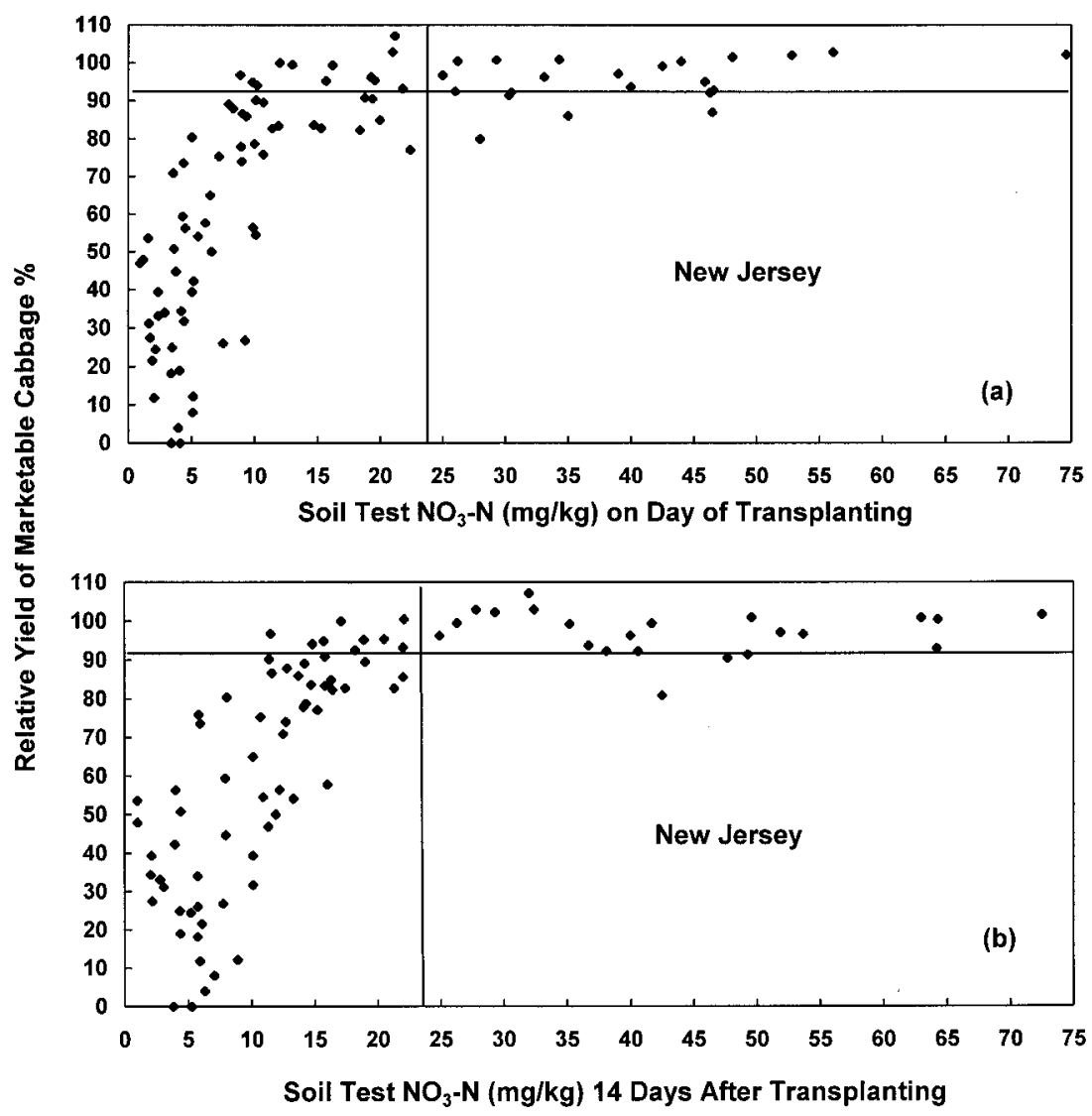

Fig. 2. Relative cabbage yield in New Jersey as a function of soil $\mathrm{NO}_{3}-\mathrm{N}$ concentration in surface $30 \mathrm{~cm}$ of soil; (a) soil samples collected on day of transplanting, (b) soil samples collected $14 \mathrm{~d}$ after transplanting. Plots were drawn using individual data points. 
experimental sites conducted from 1997 to 1999 the $\mathrm{N}$ rates were 0 and $225 \mathrm{~kg} \mathrm{~N} / \mathrm{ha}$.

Cabbage heads were harvested in late October or early November. Twenty-four plants from the six center rows of each plot were harvested by hand. The heads were graded into marketable and nonmarketable $(<10 \mathrm{~cm}$ diameter) heads. The weights of marketable and nonmarketable heads harvested per plot were recorded.

The relationship between soil $\mathrm{NO}_{3}-\mathrm{N}$ concentration and relative yield was examined using Cate-Nelson analysis (Cate and Nelson, 1971) by partitioning data into $\mathrm{N}$-responsive and nonresponsive sites. This procedure was modified by setting the horizontal line at an acceptable relative yield level of $92 \%$. The relationship was examined both by averaging the data across replications within each experimental site and also by plotting the individual data points. Relative yields for the Cate-Nelson analysis was calculated as the yield of marketable heads without sidedress $\mathrm{N}$, expressed as a percentage of the yield observed for the highest rate of sidedress $\mathrm{N}$ applied within a field calibration site. The relationship between sidedress $\mathrm{N}$ rate and relative yield was plotted for various ranges of soil $\mathrm{NO}_{3}-\mathrm{N}$ concentration. In this instance relative yield was calculated as the yield observed for a given sidedress $\mathrm{N}$ rate, expressed as a percentage of the yield observed for the highest rate of sidedress $\mathrm{N}$ applied within a field calibration site.

\section{Results and Discussion}

Cate-Nelson statistical analysis defines the critical soil $\mathrm{NO}_{3}-\mathrm{N}$ concentration with a vertical line (Fig $1 \mathrm{a}$ and $\mathrm{b}$ ). The intersection of the vertical and horizontal lines was drawn to minimize the number of observations in the upper left quadrant (incorrect predictions of a need for sidedress $N$ ) and the lower right quadrant (incorrect predictions that sidedress $\mathrm{N}$ is not needed.) The critical soil $\mathrm{NO}_{3}-\mathrm{N}$ concentration is the same whether the relationship is examined by averaging the data across replications within each experimental site (Fig. 1a) or by plotting individual data points (Fig. 1b). The second approach, however, has the advantage of including a wider range of soil $\mathrm{NO}_{3}-\mathrm{N}$ concentrations to better define the soil $\mathrm{NO}_{3}-\mathrm{N}$ critical concentration.

The 24-mg NO $3-\mathrm{N} / \mathrm{kg}$ critical concentration correctly predicts the need for sidedress $\mathrm{N} 84 \%$ of the time (Fig. 1b). Use of the 24- $\mathrm{mg}^{-\mathrm{kg}^{-1}}$ critical concentration would have incorrectly predicted a need for sidedress $\mathrm{N}$ when no fertilizer was needed for $\approx 8 \%$ of the experimental plots. Ten experimental plots are located in the lower right quadrant, where the test incorrectly predicts no need for sidedress $\mathrm{N}$ when there probably is a need for $\mathrm{N}$, but these 10 plots would have needed only a small amount of fertilizer because they achieved close to $90 \%$ maximum yield. An environmental factor that may account for some of the incorrect predictions of no need for sidedress $\mathrm{N}$ when some $\mathrm{N}$ was needed, is that fall cabbage growth and $\mathrm{N}$ uptake continue into October and early November when soil tempera-

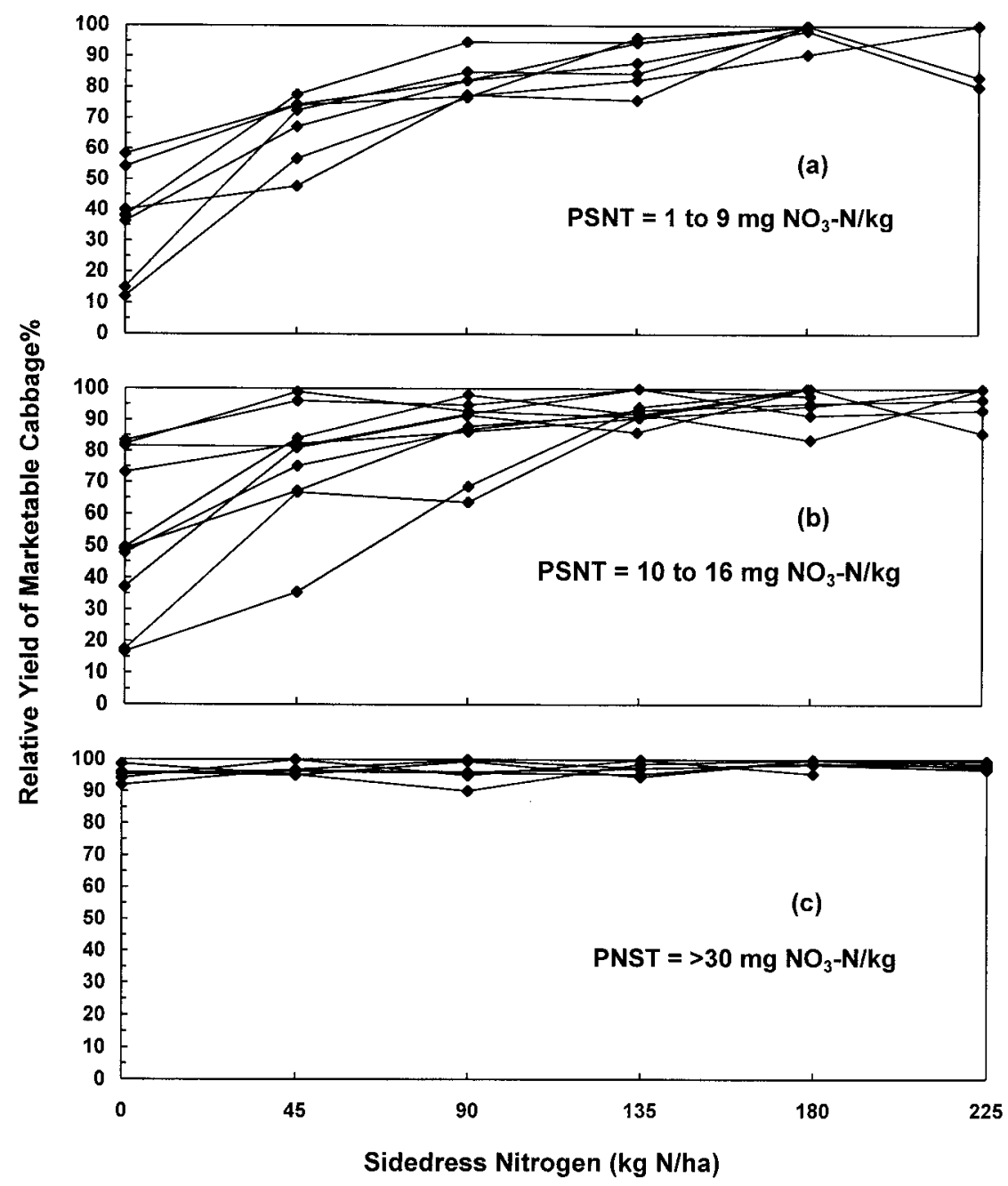

Fig. 3. Relative cabbage yield as a function of sidedress $\mathrm{N}$ application rate; (a) PSNT values were in the range of 1 to $9 \mathrm{mg} \mathrm{NO}-\mathrm{N} / \mathrm{kg}$; (b) PSNT values were in the range of 10 to $16 \mathrm{mg} \mathrm{NO}-\mathrm{N} / \mathrm{kg}$, (c) PSNT values were $>30 \mathrm{mg} \mathrm{NO}_{3}-\mathrm{N} / \mathrm{kg}$.

tures and $\mathrm{N}$ mineralization may be decreasing. This prediction rate we are reporting for cabbage is about the same as reported for use of the PSNT on sweet corn in New Jersey (Heckman et al., 1995) and for field corn in many states (Fox et al., 1989; Heckman et al., 1996; Klausner et al., 1993; Sims et al., 1995).

The critical concentration of $24 \mathrm{mg}$ $\mathrm{NO}_{3}-\mathrm{N} / \mathrm{kg}$ identified for fall cabbage in this study is similar to the PSNT critical concentration of 25 for sweet corn (Heckman et al., 1995), 20 to 25 for field corn (Blackmer et al., 1989; Fox et al., 1989; Heckman et al., 1996; Klausner et al., 1993; Magdoff et. al., 1984; Messinger et al., 1992; Sims et al., 1995), and $20 \mathrm{mg} \mathrm{NO}_{3}-\mathrm{N} / \mathrm{kg}$ for lettuce and celery (Hartz et al., 2000).

In New Jersey, soil samples taken from 20 sites both at the time of transplanting and 14 days after transplanting examined the effect of PSNT soil sampling time on the ability of the PSNT to accurately predict crop need for sidedressing. Soil $\mathrm{NO}_{3}-\mathrm{N}$ concentrations usually increased from the initial level measured at transplanting to the level measured $14 \mathrm{~d}$ later. When comparing 80 plots sampled at transplanting and again $14 \mathrm{~d}$ later, $69 \%$ of
PSNT concentrations increased and $29 \%$ decreased. Soil $\mathrm{NO}_{3}-\mathrm{N}$ concentrations increased $(P=0.001)$ on average from $20 \mathrm{mg} / \mathrm{kg}$ at transplanting to $25 \mathrm{mg} \cdot \mathrm{kg}^{-1} 14 \mathrm{~d}$ later. Results suggest that in most cases decomposing residue from sweet corn does not cause immobilization of soil mineral $\mathrm{N}$. The tillage that was performed to incorporate sweet corn residue and to prepare fields for planting cabbage probably stimulated mineralization of soil organic matter. Although the relationship (Fig. 2 ) between soil $\mathrm{NO}_{3}-\mathrm{N}$ concentration and relative yield of cabbage was similar for both PSNT sampling dates, there were fewer incorrect predictions of the need for sidedress $\mathrm{N}$ when the later PSNT sampling date was used The advantage of waiting for a period after transplanting to take the PSNT sample is that it allows $\mathrm{N}$ mineralization to occur which may then be accounted for in sidedress $\mathrm{N}$ decisions. But soil sampling at time of transplanting may also be useful for identifying fields with very low $\mathrm{N}$ availability that may benefit from $\mathrm{N}$ fertilizer applied at an earlier date to newly transplanted cabbage.

The correlation between relative yield and soil $\mathrm{NO}_{3}-\mathrm{N}\left(\mathrm{y}=3.59 \mathrm{x}+17.9, \mathrm{x} \leq 24, r^{2}=0.51\right)$ 

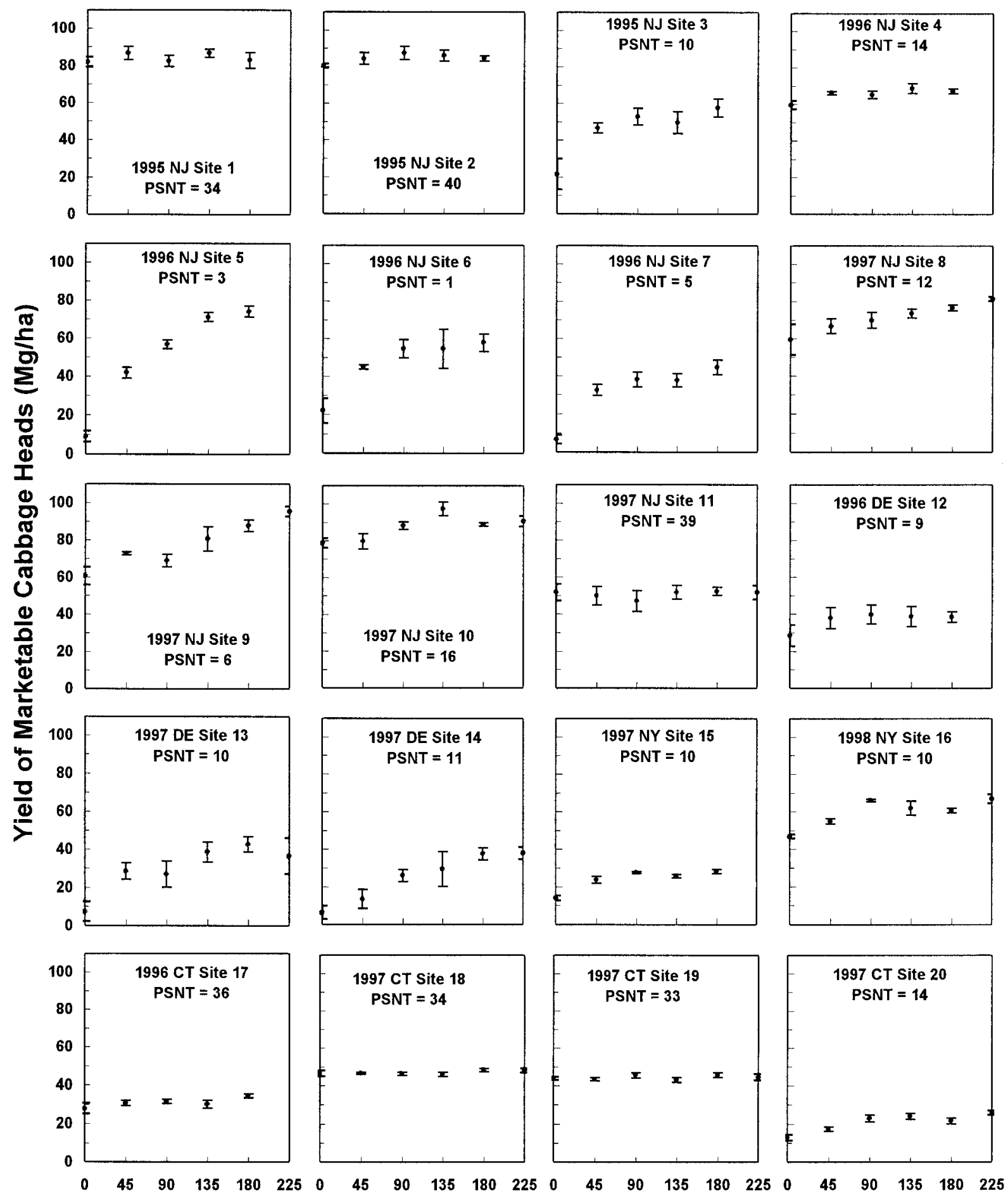

Sidedress Nitrogen (kg N/ha)

Fig. 4. Cabbage yield as a function of sidedress $\mathrm{N}$ application rate at 11 experiment sites in New Jersey, 3 in Delaware, 2 in New York, and 4 in Connecticut.

suggests that when the PSNT is lower than the critical concentration, it may provide limited guidance in predicting the required application rate of sidedress N. PSNT values $9 \mathrm{mg}$ $\mathrm{NO}_{3}-\mathrm{N} / \mathrm{kg}$ or less were associated with cabbage yields that were $<60 \%$ of maximum yield (Fig. 1a) and required sidedress $\mathrm{N}$ applications of 90 to $180 \mathrm{~kg} \mathrm{~N} / \mathrm{ha}$ to achieve yields greater than $90 \%$ of maximum yield (Fig. 3a). Values in the range of 10 to $16 \mathrm{mg} \mathrm{NO}_{3}-\mathrm{N} / \mathrm{kg}$ required sidedress $\mathrm{N}$ applications of 45 to $135 \mathrm{~kg} \mathrm{~N} / \mathrm{ha}$
(Fig. 3b). When soil $\mathrm{NO}_{3}-\mathrm{N}$ concentrations were greater than $30 \mathrm{mg} \mathrm{NO}_{3}-\mathrm{N} / \mathrm{kg}$, there were no yield responses to any application rate of sidedress N (Fig. 3c).

Considerable variation in yield was measured in our 20 field experiments in four states where various rates of sidedress $\mathrm{N}$ were applied (Fig. 4). At some experimental sites cabbage yields were low due to excessive rainfall and flooding (Fig. 4, Sites 12 and 17) or due to early on-set of cold weather
(Fig. 4, Sites 15, 18, 19, and 20). In field experiments with low PSNT values there were generally large responses to increasing rates of sidedress $\mathrm{N}$ if cabbage yields were $>60 \mathrm{Mg} \cdot \mathrm{ha}^{-1}$. When yields were low due to unfavorable growing conditions there was less response to sidedress N. Results suggest that PSNT values below the critical concentration are useful for predicting rates of sidedress $\mathrm{N}$ when conditions are favorable for cabbage production. Current $\mathrm{N}$ recommenda- 
tions for cabbage in states in the Mid-Atlantic region range from 112 to $168 \mathrm{~kg} \mathrm{~N} / \mathrm{ha}$. Based on the responses observed in this study these $\mathrm{N}$ application rates are adequate for fall cabbage grown on soils with PSNT values below the critical level and the PSNT may be used to inversely adjust fertilizer $\mathrm{N}$ application rates accordingly. Our results are in general agreement with research in the Netherlands (Everaarts and De Moel, 1998) which showed that mineral $\mathrm{N}$ in the soil (0 to $60 \mathrm{~cm}$ depth) could be credited towards a reduction in the $\mathrm{N}$ fertilizer application rate for cabbage.

In conclusion, the PSNT, which measures the concentration of $\mathrm{NO}_{3}-\mathrm{N}$ in the surface $30 \mathrm{~cm}$ of soil, is useful for predicting whether fall cabbage is likely to respond to sidedress $\mathrm{N}$ fertilizer. When the PSNT is $\geq 24 \mathrm{mg}$ $\mathrm{NO}_{3}-\mathrm{N} / \mathrm{kg}$ fall cabbage is not likely to need sidedress $\mathrm{N}$ fertilizer, but when the PSNT is $<24 \mathrm{mg} \mathrm{NO} \mathrm{N}_{3}-\mathrm{N} / \mathrm{kg}$ sidedress $\mathrm{N}$ is likely to be needed. Soil $\mathrm{NO}_{3}-\mathrm{N}$ concentrations below the PSNT critical concentration are useful to inversely adjust recommended rates of sidedress $\mathrm{N}$ fertilizer. When soil $\mathrm{NO}_{3}-\mathrm{N}$ concentrations of $9 \mathrm{mg} \cdot \mathrm{kg}^{-1}$ or less occur the full standard recommended rates of $\mathrm{N}$ (112 to $168 \mathrm{~kg} \cdot \mathrm{ha}^{-1}$ ) should be applied. For soil $\mathrm{NO}_{3}-\mathrm{N}$ concentrations in the range of 10 to $23 \mathrm{mg} \cdot \mathrm{kg}^{-1}$, recommended $\mathrm{N}$ rates may be reduced by $25 \%$ to $50 \%$ or more. The success of the PSNT with cabbage suggests that the practice of soil nitrate testing may be extendable to other cole crops with similar $\mathrm{N}$ requirements.

\section{Literature Cited}

Binford, G.D., A.M. Blackmer, and M.E. Cerrato 1992. Relationships between corn yields and soil nitrate in late spring. Agron. J. 84:53-59.

Blackmer, A.M., D. Potter, M.E. Cerrato, and J. Webb. 1989. Correlations between soil nitrate concentrations in late spring and corn yield in Iowa. J. Prod. Agr. 2:103-109.

Cate, R.B. and L.A. Nelson. 1971. A simple statistical procedure for partitioning soil test correlation into two classes. Soil Sci. Soc. Amer. Proc. 35:658-660.

Durieux, R.P., H.J. Brown, E.J. Stewart, J.Q. Zhao, W.E. Jokela, and F.R. Magdoff. 1995. Implications of nitrogen management strategies for nitrate leaching potential: Roles of nitrogen source and fertilizer recommendation system. Agron J. 87:884-887.

Everaarts, A.P. and C.P. De Moel. 1998. The effect of nitrogen and method of application on yield and quality of white cabbage. European J. of Agron. 9:203-211.

Fox, R.H., G.W. Roth, K.V. Iverson, and W.P Piekielek. 1989. Soil and tissue nitrate tests compared for predicting soil nitrogen availability to corn. Agron. J. 81: 971-974.

Griffin, G., W. Jokela, and D. Ross. 1995. Recommended soil nitrate $\mathrm{N}$ tests, p. 22-29. In: Recommended soil testing procedures for the northeastern United States. Northeast Regional Publ. 493. Agr. Expt. Sta., Univ. of Delaware. Newark.

Guillard, K., T.F. Morris, and K.L. Kopp. 1999. The pre-sidedress soil nitrate test and nitrate leaching from corn. J. Environ. Qual. 28:1845-1852.

Hartz, T.K., W.E. Bendixen, and L. Wierdsma. 2000. The value of Pre-sidedress soil nitrate testing as a nitrogen management tool in irrigated vegetable production. HortScience 35: 651-656.

Heckman, J.R., R. Govindasamy, D.J. Prostak, R.C. Mickel, and E.P. Prostko. 1996. Corn response to sidedress nitrogen in relation to soil nitrate concentration. Commun. Soil Sci. Plant Anal. 27: $575-583$

Heckman, J.R., W.T. Hlubik, D.J., Prostak, and J.W. Paterson. 1995. Pre-sidedress soil nitrate test for sweet corn. HortScience 30:10331036.

Klausner, S.D., W.S. Reid, and D.R. Bouldin. 1993. Relationship between late spring soil nitrate concentrations and corn yields in New York. J. Prod. Agr. 6: 350-354.

Meissinger, J.J., V.A. Bandel, J.S. Angle, B.E. O'Keefe, and C.M. Reynolds. 1992. Presidedress soil nitrate test evaluation in Maryland. Soil Sci. Soc. Amer. J. 56:1527-1532.

Magdoff, F.R. 1991. Understanding the Magdoff pre-sidedress nitrate test for corn. J. Prod. Agr. 4:297-305.

Magdoff, F.R., D. Ross, and J. Amadon, 1984. A soil test for nitrogen availability to corn. Soil Sci. Soc. Amer. J. 48:1301-1304. 